\title{
Willful Control and Controlling the Will: Technology and Being Human
}

\section{Brent Waters}

Garrett-Evangelical Theological Seminary, Evanston 60201, USA; brent.waters@garrett.edu; Tel.: +1-847-866-3933

Academic Editor: Noreen Herzfeld

Received: 23 February 2017; Accepted: 8 May 2017; Published: 10 May 2017

\begin{abstract}
One purported benefit of technology is that it gives humans greater control over how they live their lives. Various technologies are used to protect humans from what are perceived to be the capricious whims of indifferent natural forces. Additionally, technology is used to create circumstances and opportunities that are believed to be preferable because they are more subject to human control. In large measure, the lives of late moderns are effectively constructed and asserted as artifacts of what they will themselves to be. This control is seen prominently at the beginning and end of life. Technology is employed to overcome infertility, prevent illness, disability, and undesirable traits, to select desirable traits and increasingly enhance them. At the end of life, late moderns have a far greater range of options at their disposal than past generations: they can choose to delay death, control pain, or end their lives at the time and with the means of their choosing. The greater control that technology offers helps humans to survive and even flourish, but it comes at a price. One such cost is that it tends to reduce humans to being little more than a will confined within a body. The body is thereby effectively perceived to be an impediment to the will that should be overcome. Is this troubling? Yes. I argue that the purported control technology offers often serves as a distraction or blind spot that may prevent humans from understanding and consenting to their good. In making this argument I draw upon the Christian doctrine of the incarnation as a way of disclosing the creaturely good of finitude against which the will should conform rather than attempting to overcome. I also draw upon Iris Murdoch's and Simone Weil's concept of "unselfing" as a way of conforming the will with this good. I revisit issues related to the beginning and end of life to draw-out some of the implications of my argument.
\end{abstract}

Keywords: technology; ontology; will; mastery; Hannah Arendt; George Grant; Iris Murdoch

The word "technology" engenders a range of responses. For some, it evokes a highly positive reaction. With the aid of various technologies humans can, over time, fashion for themselves a virtual heaven on earth. For others, technology conjures a grave threat. Devices are invading every aspect of life, collectively diminishing its quality and perhaps ending in the extinction of the human species. For most, however, technology is taken for granted. Ubiquitous gadgets are part of the fabric of everyday life, and the significant role they play in weaving that fabric is largely unnoticed, except on those relatively rare occasions when they fail to perform as expected. For example, who thinks about electricity until there is a power failure?

In this article, I focus on this latter group, who have easily embraced a manufactured habitat as their normal environment. What would have appeared to previous generations as a magical world is now commonplace. I assume that one of the primary reasons for this easy embrace is the functionality or utility that technology affords. Computers, mobile phones, dishwashers, cars, airplanes, and the countless other items that could be added to this list make our lives easier, productive, and more entertaining. And I have no quarrel with affirming these benefits. Yet what does this easy embrace disclose and occlude about what being human is coming to mean for late moderns? In the following 
inquiry, I offer some provisional thoughts about this question by concentrating on the relation between technology and asserting greater control, and assessing the some of the costs incurred in such an assertion in respect to human ontology.

Presumably one of the chief benefits of technology (referred to here as the collection of devices used to achieve various goals and objectives) is that it enables humans to assert greater control over the circumstances they encounter. Indeed, these circumstances are increasingly manufactured by humans. Many, if not most, late moderns live and work in environments of their own making, and are thereby also subject to their control. Presumably, this control improves the quality of being human. It is difficult to object to this presumption. Who would want to return to a status in which humans were largely at the mercy of natural processes that are indifferent to our survival, much less our flourishment? Technology is merely a tool that humankind, as homo faber, uses to fashion a hospitable habitat. Without tools, humans are something less than human. The world, then, into which people are born is not a given, but a human artifact. As Hannah Arendt recognized, the world "is the result of human productivity and human action" (Arendt 2005, p. 107). The world "is not identical with the earth or with nature", but a "human artifact, the fabrication of human hands" (Arendt 1998, p. 52).

As George Grant declares: "In each lived moment of our waking and sleeping, we are technological civilisation" (Grant 1986, p. 11). These waking and sleeping moments disclose an obsessive drive for asserting greater mastery over nature and human nature (Grant 1969; Grant 1995; Grant 1985). Grant's references to "nature" and "human nature" in the works cited are admittedly cryptic, but what he has in mind is the late modern project of creating a world more amenable to human purposes. In the "will to mastery", humans make things happen (Grant 1986, pp. 12-13). Through employing technology, humans transform nature into resources that both expand the range of available options, while diminishing the threat of chance or randomness. Asserting such mastery is thereby relentless and progressive, as reflected in the late modern belief that the chief accomplishments of a civilization are measured by its ability to predict, construct, and control the future. Moreover, technology is used to achieve a relative equality among people, compensating the disadvantages the natural lottery distributes to some unfortunate individuals. More just societies can be engineered, and unwanted outcomes of natural selection can be ameliorated. In short, it is through technology that humans create a world as their suitable habitat for being human.

Asserting such mastery, however, is not an extrinsic act, but reveals the will to mastery as intrinsic to being human, especially to late moderns. It is in this willing that humans free themselves from the constraints of nature and human nature to become more fully human (Arendt 1978, pp. 3-5). Consequently, nature and human nature are effectively transformed into artifacts of the human will. Nature is little more than raw material that may be used or abused, cherished or despised in accordance to its assigned valuation. Pristine wilderness may be farmed, mined, developed, or preserved, but each instance is the outcome of what is willed. Human nature as well is an artifact of the will. Behavior, for instance, is controlled through incentives and disincentives, therapy, drugs, and perhaps someday extensive genetic modification.

Even such universal natural events as birth and death are increasingly subjected to technological control. Fetal development is routinely monitored, and in some instances tested. Infertility can be overcome through drugs, gamete donation, artificial insemination, in vitro fertilization (IVF), and surrogacy. A variety of techniques-such as fetal screening and abortion, or IVF and preimplantation genetic diagnosis (PGD) - may be used to prevent the birth of children with severe illnesses or disabilities. More broadly, these same technologies may be employed to avoid undesirable traits or select desirable ones. Should safe and reliable technologies be developed, selected genetic traits may someday be enhanced. At the end of life, various drugs and medical procedures alleviate pain. Increasingly, death itself is becoming more a matter of choice than necessity. Patients can choose to prolong their lives, delay their deaths, or be assisted in dying at a time and means of their choosing. The beginning and end of life, as well as the time in between, are now more artifacts of the will than a natural unfolding of a human life. 
Is it wrong or bad to assert greater mastery over nature and human nature? The answer for most late moderns is presumably no, for they turn to technology more and more in living out their lives. In many respects, the lives of late moderns are more akin to a project than an accident or gift. And projects must be managed, and such managing requires tools, and the more sophisticated and efficient tools are at hand, the better. Moreover, it is difficult to argue against asserting greater mastery given the obvious and expansive range of benefits it has provided. Late moderns are exceedingly healthier, richer, and more comfortable than their ancestors, and their descendants will be even better off, provided some foreseen calamities can be avoided or unforeseen disasters do not occur. Technology has not only assisted the survival of the human species in untold ways, but has also enabled human flourishing. Being in control enriches the human condition, so how can asserting greater mastery over nature and human be a problem, or even troubling?

Critics may be quick to complain that, to the contrary, there is much to worry about: examples such as ecological degradation, diminished privacy, weapons of mass destruction, hybrids and chimeras, robots and artificial intelligence enslaving or obliterating humankind come readily to mind. Every technology has the potential to be misused or go terribly awry in unexpected ways. In asserting greater mastery, humans are becoming mastered by their own technology, ultimately imperiling their wellbeing, and perhaps even their survival. These critics may be offered the rejoinder, however, that many problems have already been identified and are being addressed; have they not heard, for instance, of green technologies? Moreover, many of the concerns raised are potential rather than real and can be avoided. The tools used to assert mastery over nature and human nature are controlled by their users who determine how they shall and shall not be used. Since Hiroshima and Nagasaki, no atomic or nuclear weapons have been used in a war, and measures have been taken to limit their proliferation. Granted, unintended consequences cannot be predicted or always prevented, but no progress can be achieved without taking acceptable risks. The benefits incurred to date have far outpaced any problems encountered.

There is much truth in the proponents' question and rejoinder to skeptics. To have greater control over one's circumstances and destiny is not inevitably problematic or troubling. There is no compelling reason to question, much less deny, that technology has, over time, improved the human condition. But the question and rejoinder ignore an important follow-up question: what is the cost? Asserting greater control is not free. George Grant was fond of quoting a Spanish proverb: "Take what you want, said God-take it and pay for it" (Grant 1986, p. 9). Humans pay a price for asserting greater mastery, but has the cost been exorbitant or reasonable? I do not know the answer to this question, but in what follows I identify some of the costs without assigning a precise valuation to the price.

One cost is that human identity, both individually and collectively, is increasingly reduced to acts of the will. This is understandable, perhaps unavoidable in any attempt to master, for to master something requires willing its mastery; a will to mastery. To be in control is to also be more fully human, and this fulfilment is accomplished by imprinting the human will on the world, and on human lives within the world that they make. Late moderns cannot simply say "let it be", but must add the words "thus and so". To be fully human is to make and to master. To effectively reduce what being human means to willful mastery, however, is to render embodiment problematic. The body becomes a problem to be solved, because to be embodied constrains and frustrates the will. I cannot simply will myself to be an athlete, mathematical wizard, or live forever. Nonetheless, asserting greater mastery achieves small victories over finitude that accrue over time; increasingly, nature and human nature are becoming artifacts of the will.

As mentioned above, there is much to say in favor of asserting such mastery. Human flourishing is wider and deeper when humans are steadily less at the mercy of indifferent natural processes. But there is a price to be paid, particularly in "solving" the "problem" of embodiment. One possible cost is that being in control may serve to distract. Control is properly a means rather than an end. One controls A to achieve B. When control becomes effectively an end, then the resulting process of asserting control becomes circular. One controls A to achieve A. It is not clear what purposes late 
moderns are seeking in asserting greater control or mastery over nature and human nature. Apparently, mastery is often asserted for the sake of achieving greater mastery, but no explicit good is invoked that this mastery purportedly serves. Following Grant, late moderns are "resolute in their will to mastery, but they cannot know what that mastery is for" (Grant 1995, pp. 45-46). One practical consequence of this circular willing is that technological development becomes a default solution, thereby defining the problem a priori. Consequently, "when we are deliberating in any practical situation our judgment acts rather like a mirror which throws back the very metaphysic of the technology which we are supposed to be deliberating about in detail. The outcome is almost inevitably a decision for further technological development" (Grant 1986, p. 33). Once the relative safety of a proposed technological development can be demonstrated, the case is closed.

But why is a circular assertion of the will a distraction? It may, in part, prevent humans from discovering, understanding, and consenting to their good as creatures. To invoke the Christian doctrine of creation, humans are creatures created by God. They are willed into being by their creator. Being properly human is thereby to be more receptive than assertive. It is somewhat similar to Josef Pieper's notion of leisure as a "receptive attitude of mind, a contemplative attitude, and it is not only the occasion but also the capacity for steeping oneself in the whole of creation" (Pieper 2009, pp. 46-47). If humans are artifacts, they are divinely made rather than self-made; their being is more akin to a gift received than a construct or self-directed project. As creatures, however, humans are finite and mortal, and these qualities are part of what the good of being a creature entails. Embodiment, then, is not a problem to be solved, but the prerequisite of being creaturely; not an impediment against the will to be overcome, but a standard against which the will conforms. Human flourishing is predicated upon discovering, understanding, and consenting to the good of being finite and mortal creatures.

The doctrine of the incarnation affirms the creaturely goods of finitude and mortality. The Word became flesh; the creator became a creature. Jesus is constrained by the limits of his body-miracles notwithstanding - and he does not escape death. In the incarnation, the creaturely goods of finitude and mortality are confirmed by their created source. It is in and through their finitude and mortality that humans participate fully in the unfolding "drama of being" (Voegelin 1989, pp. 39-40). To experience being is to experience that which is lasting and that which is passing. To be an actor in the unfolding drama of being, humans must experience both life and death (Voegelin 1989, pp. 42-43). And it is in consenting to finitude and mortality that humans attune themselves to that which is genuinely lasting. This is why, in part, Christian hope is placed in death and resurrection into the eternal life of God rather than the technological transformation of human creatures into immortal beings of endless time; they look for signs of resurrection and new life rather than clutching to a life that can somehow cheat death.

To be clear, consenting to finitude and mortality does not require one to refuse ameliorating the ill effects entailed in these goods. There is nothing inherently wrong in employing technologies, especially those associated with medical care, to relieve the pain and suffering of injured or deteriorating bodies, or even to extend longevity. Nevertheless, when being human is effectively reduced to the will, to perceive embodiment, either wittingly or unwittingly, as a barrier to be overcome is a temptation difficult to resist. Rather than consenting to finitude and mortality as creaturely goods, they become enemies to be conquered. And herein lies the distraction. In fixating on the will as the paramount feature of their being, late moderns become self-absorbed. The drama of being becomes my drama. My survival, my flourishing commands one's attention. The passing is confused with the lasting, and in doing so one's life becomes discordant, for the expansive drama of being is displaced by autobiography. Rather than perceiving ourselves as participating in an unfolding saga greater and outlasting ourselves, we fixate on bit parts, and resent the prospect of being removed from the stage. In brief, to make oneself the centerpiece of the drama of being is to also remove oneself from participating fully in being human. In addition technology is proficient at reinforcing this misperceived centering.

There is no reason to deny that willful control is required in making a world suitable for human flourishing. This requires, however, that the will and what is willed must also be controlled to ensure 
that humans participate fully in the unfolding drama of being as finite and mortal creatures; that they avoid the distraction of self-absorption. But how? An extensive survey of how various philosophical and theological accounts of virtues and practices might help to remain properly focused on the passing and the lasting is beyond the scope of this article. Examining briefly Iris Murdoch's notion of "unselfing" (Antonaccio 2012; Gordon 1995; Widdows 2005), however, suggests one way for how controlling the will might be undertaken.

According to Murdoch, freedom does not consist of an isolated individual leaping "in and out of an impersonal logical complex, it is a function of the progressive attempt to see a particular object clearly" (Murdoch 2001, p. 23). Love is central to the process of gaining such clarity. It is in loving the world in general, and individuals in particular, that we come to see both more clearly in their own respective right, for in so doing we "apprehend" their related goodness that "belong(s) to a continuous fabric of being" (Murdoch 2001, p. 29). Following Simone Weil, we must cast a loving and just gaze upon the reality of the other in order to be genuinely attentive to its own good. This attentive love "can prompt a process of unselfing wherein the lover learns to see, and cherish and respect, what is not himself" (Murdoch 1993, p. 17). "If I attend properly I will have no choice and this is the ultimate condition to be aimed at" (Murdoch 2001, p. 38). The ideal situation is similar to that of a kind of necessity. Freedom is not unimpeded movement, but is more akin to the notion of obedience. "I can only choose within the world I can see, in the moral sense of 'see' which implies that clear vision is a result of moral imagination and moral effort" (Murdoch 2001, pp. 25-26). Freedom is the result of attention and not action. Consequently, the moral life is something that is formed continually, and not just confined to relatively few moments of decisions or choices.

How might unselfing help avoid the distraction of willful control or mastery? Murdoch contends: "We need a moral philosophy in which the concept of love, so rarely mentioned now by philosophers, can once again be made central" (Murdoch 2001, p. 45). When love is properly ordered, it is directed outwardly, allowing the other to be, whereas mastery is directed inwardly, controlling the other to be what is willed. To oversimplify, the will to mastery is disordered love. The consequence of this disordered love is significant. "In the moral life the enemy is the fat relentless ego" (Murdoch 2001, p. 51). The will to mastery feeds this ego relentlessly, diminishing the center of reality to the one willing and controlling. Mastery is asserted for the sake of the one asserting it. This centering of the ego is, of course, illusory, and such a fantasy, according to Murdoch, is the nemesis of moral excellence. Why? A fantasized self is incapable of attending to the other, and thereby cannot know the good of the other. The other is good only in so far as the value it is assigned by the one seeking to master and control for its own sake. This lack of loving, unselfed attention exposes the fallacy of mastery, in that the freedom purportedly offered in mastering is counterfeit. "The freedom which is a proper human goal is the freedom from fantasy" (Murdoch 2001, p. 65). Fantasy is rooted in self-centeredness, whereas attending to reality is derived from love. True freedom is more akin to proper vision than an assertive will. Reality, one that is given and engaged in rather than constructed and manipulated, is the proper object of love, and knowledge of that object is freeing. It is in this knowledge that we can will to love the neighbor as an other with its own inherent good. Moreover, it is only as finite and mortal beings that we can perceive and attend to the good of other finite and mortal beings (Murdoch 2001, pp. 96-97).

Admittedly, unselfing alone can neither prevent nor resolve the problem of mastery as a distraction. Yet it offers a promising starting point by reorienting attention, at least initially, from the will and what is willed toward encountering an external reality. Borrowing from $\mathrm{H}$. Richard Niebuhr, it entails first asking the question: what is going on? as opposed to asserting what I will to do or to make (Niebuhr 1963). Asking what is going on does not negate the will or willing, for when some determination about what is occurring is made a response must be willed, nor does starting with this question necessarily preclude willful mastery. However, it serves to help shape, and thereby control, what is willed by recasting attention away from the self to the other. To respond to the good of the 
other, especially through the lens of Murdoch's loving and just gaze, is in large measure to let the other be rather than something to be mastered.

What difference this change in orientation might entail can be illustrated by briefly revisiting the perceptions of birth and death noted earlier in this article. Late moderns increasingly perceive birth as the successfully willed outcome of a reproductive project (Robertson 1994). Hence, the greater recourse to technology in selecting the biological material, testing, and monitoring fetal development for obtaining a desirable child. The child so conceived is effectively an artifact of its progenitor's will. This perception corrodes the traditional parent-child relationship, for begetting is not synonymous with making (O'Donovan 1984). In begetting, there is a fundamental equality of being that is shared by parent and child in a mode of receptivity; a baby is received by her parents. Whereas in making, there is a distinct inequality between maker and made that is inherent in any mode of mastery; a baby is created by the overseer of a reproductive project. To perceive a baby, either wittingly or unwittingly, as an artifact is to also to strip the accompany symbolism of its moral and political import. In Arendt's account of natality (Arendt 1998), she contends that the "law of mortality" is the only certainty of human life (Arendt 1998, p. 246). Humans, however, are not born to die, but are born to begin. It is natality that rescues humans from their natural mortality. But such rescue is not achieved by attempting to overcome mortality, but receiving the future through regeneration. To control the outcome of a reproductive project is in effect to deny the future by extending and instantiating a willed present in which nothing new can be received. The possibility of new and unanticipated beginnings, a possibility symbolized in begetting a child, is what gives men and women their faith and hope. It is the hope that is expressed in the Christian "glad tidings" of Jesus' birth: "A child has been born unto us" (Arendt 1998, p. 247).

Likewise, when death is perceived as more a matter of choice than a necessity, it ceases to be a fitting end to one's role in the unfolding drama of being. To play this role requires the actor to both live and die, and to play it well entails consenting to these necessities. Choosing the time and means of one's death is simply a final, defiant, and futile act of will; one last, empty attempt to protect the present from the future. In waging a lifelong war against finitude and mortality, the only end to be imagined is to control one's demise. This is tantamount to refusing to participate in the drama of being, because one never consents to the prerequisites of finitude and mortality; one cannot be unless one foresees and accepts ceasing to be. Moreover, refusing to participate is to essentially commit the deadly sin of acedia- a fundamental boredom and indifference to being itself. Ironically, the will to mastery is a denial of being, for humans were created to be recipients of life rather than its makers. The will to mastery is ultimately deadly.

To reiterate, unselfing alone cannot control what is willed in our inevitable acts of asserting willful control, but it does serve to remind that no one is at the center of being; the drama of the passing and the lasting is far larger. Unselfing may also serve to remind that humans should endeavor to remain creaturely for that is what they were created to be. Consequently, technology should be used in ways that assist humans to consent to their creaturely finitude and mortality rather than attempting to vanquish them through their mastery. Perhaps in reinforcing such unselfed consent, we might also gain some greater insight into what being human and human being might mean.

Conflicts of Interest: The author declares no conflict of interest.

\section{References}

Antonaccio, Maria. 2012. A Philosophy to Live By: Engaging Iris Murdoch. Oxford and New York: Oxford University Press. Arendt, Hannah. 1978. The Life of the Mind: Two, Willing. San Diego and London: Harcourt.

Arendt, Hannah. 1998. The Human Condition. Chicago and London: University of Chicago Press.

Arendt, Hannah. 2005. The Promise of Politics. New York: Shocken Books.

Gordon, David J. 1995. Iris Murdoch's Fables of Unselfing. Columbia: University of Missouri Press.

Grant, George. 1969. Technology and Empire: Perspectives on North America. Toronto: House of Anansi.

Grant, George Parkin. 1985. English-Speaking Justice. Notre Dame: University of Notre Dame Press. 
Grant, George Parkin. 1986. Technology and Justice. Notre Dame: Notre Dame University Press.

Grant, George. 1995. Time as History. Toronto and London: University of Toronto Press.

Murdoch, Iris. 1993. Metaphysics as a Guide to Morals. London and New York: Penguin Books.

Murdoch, Iris. 2001. The Sovereignty of Good. London and New York: Routledge.

Niebuhr, H. Richard. 1963. The Responsible Self: An Essay in Christian Moral Philosophy. New York and London: Harper and Row.

O'Donovan, Oliver. 1984. Begotten or Made? Oxford: Oxford University Press.

Pieper, Josef. 2009. Leisure the Basis of Culture and the Philosophical Act. San Francisco: Ignatius Press.

Robertson, John A. 1994. Children of Choice: Freedom and the New Reproductive Technologies. Princeton: Princeton University Press.

Voegelin, Eric. 1989. Collected Works, Vol. 14: Order and History, Vol. 1: Israel and Revelation. Baton Rouge: Louisiana State University Press.

Widdows, Heather. 2005. The Moral Vision of Iris Murdoch. Aldershot and Burlington: Ashgate.

(C) 2017 by the author. Licensee MDPI, Basel, Switzerland. This article is an open access article distributed under the terms and conditions of the Creative Commons Attribution (CC BY) license (http://creativecommons.org/licenses/by/4.0/). 